\title{
Biodiversity studies through public-private partnership (PPP): The case of Fazenda São Nicolau in the northwest of Mato Grosso
}

\section{DOMINGOS J. RODRIGUES, FERNANDO Z. VAZ-DE-MELLO AND ROBERTO M.L. SILVEIRA}

Department of Botany and Ecology, Institute of Biosciences, Federal University of Mato Grosso, Av. Fernando Correia, no. 2367, Boa Esperança, 78060-900 Cuiabá, MT, Brazil

Manuscript received on February 1, 2019; accepted for publication on May 3, 2019

\begin{abstract}
How to cite: RODRIGUES DJ, VAZ-DE-MELLO FZ AND SILVEIRA RM. 2019. Biodiversity studies through public-private partnership (PPP): The case of Fazenda São Nicolau in the northwest of Mato Grosso. An Acad Bras Cienc 91: e20190097. DOI 10.1590/0001-3765201920190097.
\end{abstract}

\begin{abstract}
Peugeot-ONF Forest Carbon Sink Project, located at Fazenda São Nicolau (FSN) in Cotriguaçu Municipality, is a public-private initiative and has been supported by several French and Brazilian institutions. Its Research Program includes studies aiming Biodiversity Conservation, Ecology, Carbon Dynamics, Silvicultural Techniques. FSN comprises a high richness of species with more than 20 new species of beetles (Histeridae, Scarabaeidae e Melolonthidae) described among them one endemic genus. A quick overview of the SuperFamily Scarabaeoidea within the FSN area registered 260 species which nearly 100 species might be new to Science. One new species of fish as well as research with amphibian toxins as tools to treat cancer and malaria are also done with material collected at the FSN. Ecology of the decomposer's fauna at reforestation sites showed that after 10 years, such places were more similar to native forest sites than pastures or abandoned pastures. Finally large mammals studies indicated that many large mammals use FSN as a refuge. We stress the importance to keep the FSN natural habitats linked with the Juruena National Park. The FSN contour is under heavy deforestation which will increase the species loss and turn FSN in one of the few major natural vegetation fragments.
\end{abstract}

Key words: conservation, Amazon, Carbon Sink Project, refugee.

\section{INTRODUCTION}

Fazenda São Nicolau is the headquarter of Peugeot-ONF Forest Carbon Sink Project located at Cotriguaçu municipality, Northwest of Mato Grosso State in Brazil's Midwest. The Project was idealized by Peugeot and has been implemented by the French National Forestry Service (ONF) since its beginning in 1998. Both Peugeot and ONF have been funding the Project with the main objective of

Correspondence to: Roberto Moraes Lima Silveira

E-mail: robertomlsilveira@gmail.com

ORCid: https://orcid.org/0000-0002-7306-0835 reforesting 2,000 hectares of pasture and monitor the associated carbon sequestration until 2038.

Fazenda São Nicolau, a rural property of 10,000 hectares, divided in three major areas, comprising a surrounding belt of 7,000 hectares of native forest, including 1,815 hectares designated as a Natural Heritage Private Reserve (RPPN); 2,000 hectares of reforestation over old pasture and 1,000 hectares of abandoned pasture and riparian vegetation.

Reforestation was mainly conducted from 1999 to 2004 with over two million trees planted which included 48 native species and two exotic species 
(Tectona grandis and Syzygium jambolanum). Ten species were successful and constitute the bulk of the planted trees, with exotic species trees corresponding to less than $20 \%$.

Carbon sequestration recovered close to 1 million ton of $\mathrm{CO}_{2}$ from the atmosphere since 1999. Most of the reforestation site is already certified by the Verified Carbon Standard (VCS) (http://www. vcsprojectdatabase.org/\#/project_details/665) and steps have been taken to obtain carbon credits in the Voluntary Carbon Market. All the income obtained with carbon credits is invested in the Project Research Program.

Although not being conceived as an academic research project, the Peugeot-ONF Forest Carbon Sink Project has been assisted by a volunteer Consultative Scientific Committee (CSC) since 2001. Members of the CSC are well known senior researchers from International and Brazilian universities and research institutes. The CSC helped shape and develop a Research Program for the Carbon Sink Project, and advised research projects conducted in the area.

\section{RESEARCH PROGRAMS}

The main research areas of the Project are Carbon Dynamics, Biodiversity, Forestry, Socioeconomic Studies and Environmental Education. Nearly 10,000 visitors have already attended to the Environmental Education Program, including school students and teachers of the Cotriguaçu and Juruena municipalities.

Studies of Carbon Dynamics and Forestry are closely associated as carbon sequestration progress is measured throughout tree growing measurements (Nunes et. al. 2013) and allometric equations. Some carbon studies addressed soil carbon dynamics (Cerri et. al. 2007, Moreira et. al. 2009) and some forestry studies are currently developing the local models to recover depleted riparian vegetation zones.
Socio-economic studies are based on the Project's understanding that preservation of the native forest and reduction of deforestation pressure requires the assessment of the needs of the population living in nearby settlements. The Project encouraged peasants to collect Brazil nuts inside the Fazenda São Nicolau and to sell them for their own profit. Other similar initiatives were proposed and tested by the Project, such as agroforestry systems, woodwork professional capacitation classes, and detailed studies of the productive chain in the region. Socio-economic studies were implemented through a program titled Experimental Platform for Amazon Rural Territories Management (PETRA) funded by the French Global Environment Facility (FFEM), implemented from 2013 to 2018.

Biodiversity studies are also very productive within the many natural and man-made landscapes of the Fazenda São Nicolau. After the main part of the reforestation was established, researchers started to increase their activities at Fazenda São Nicolau. Ecology field classes for Post-Graduate Programs of the Federal University of Mato Grosso, several masters dissertations and doctoral thesis from Brazilian and French universities were also conducted in the area. The close partnership between researchers and the Project has produced over 40 scientific publications, most of them in the Biodiversity field of knowledge.

New species have been discovered in the Fazenda São Nicolau, including a species of fish (Ingenito et al. 2013), 23 species of beetles (Genier 2010, Frolov et al. 2017, Nunes et al. 2018), comprising eight species of Scarabeidae and 15 species of Histeridae. Six of the new species of Scarabeidae have their holotype designated from material collected in the Fazenda São Nicolau, and four are exclusively known from the Fazenda São Nicolau. Currently one species of bird is being studied as a possible undescribed species. Many more are yet to be described based on material that is still under examination by specialists. 
Biodiversity components with medical applications are also under investigation, including frogs that produce toxins that can provide treatments for malaria and cancer (Ferreira et al. 2013, Banfi et al. 2016, Kerkhoff et al. 2016, Ferreira et al. 2017). Other studies targeted the value of reforestation comparing undisturbed native forest sites with pasture and abandoned pasture sites. These sites were compared based on species abundance, species richness and functional diversity of termites as indicators of nutrient availability through decomposition. Reforestation sites were found to be similar to undisturbed native forest sites, showing that after 15 years the young planted forest developed a healthy nutrient cycling process (Paula et al. 2015).

A doctoral study of mammal activity using camera traps has shown that nearly half of the large mammals have been affected by deforestation outside the Fazenda São Nicolau. In native forest sites $25 \%$ of the large mammals increased their presence as a result of escaping from habitat loss outside the Fazenda, and 12\% decreased their activity in the area, possibly as a consequence of the rising activity of other species. Jaguar (Panthera onca) increased its activity both at the native forest and the reforestation sites. This increase was closely followed by the reduction of activity of the tapir (Tapirus terrestris), and the elimination of puma (Puma concolor) in both areas (Trinca 2014).

\section{FINAL REMARKS}

Considering the steady increasing loss of habitat due to deforestation near the Fazenda São Nicolau, it is recommended ecological corridors connect the Fazenda São Nicolau to other large areas of forest, such as indian reservations and conservation units.

The Project has achieved considerable success assessing the biodiversity in the area, particularly identifying and describing new species. Very little is known of the biodiversity in the Northwest of
Mato Grosso, and not much is understood about the process of recovery of abandoned pasture areas or the best model to recover deforested areas. The need for such knowledge makes the Peugeot-ONF Forest Carbon Sink Project a high-value open natural laboratory. Further research is encouraged and new partnerships are always welcomed.

\section{ACKNOWLEDGMENTS}

We are thankful for the Project's Scientific Committee members that advised the authors during the preparation of this short communication, to Peugeot and ONF support in the form of funding and providing logistical assistance in the field. We also thank Coordenação de Aperfeiçoamento de Pessoal de Nível Superior (CAPES) and Conselho Nacional de Desenvolvimento Científico e Tecnológico ( $\mathrm{CNPq}$ ) agencies for their support funding several researches and providing students' scholarship grants.

\section{AUTHOR CONTRIBUTIONS}

Dr. DOMINGOS J. RODRIGUES is a key person regarding studies with several groups of species in this Project, was able to coordinate species inventory projects as well as provided information regarding amphibian related researches. Dr. FERNANDO Z. VAZ-DE-MELLO is the person responsible for the description of some or provided support to describe the several new species of beetle. Dr. ROBERTO M.L. SILVEIRA wrote and organized the manuscript as well as verified the information regarding other branches of research within the Peugeot-ONF Carbon Sink Project. He also is one of the authors of the termite research presented in the text.

\section{REFERENCES}

BANFI FF, DE SENA GUEDES K, ANDRIGHETTI CR, AGUIAR AC, DEBIASI BW, DA COSTA NORONHA J AND SANCHEZ BAM. 2016. Antiplasmodial and 
cytotoxic activities of toad venoms from Southern Amazon, Brazil. Korean J Parasitol 54: 415-421.

CERRI CEP, EASTER M, PAUSTIAN K, KILLIAN K, COLEMAN K, BERNOUX M AND CERRI CC. 2007. Predicted soil organic carbon stocks and changes in the Brazilian Amazon between 2000 and 2030. Agric Ecosyst Environ 122: 58-72.

FERREIRA PMP ET AL. 2017. Marinobufagin, a molecule from poisonous frogs, causes biochemical, morphological and cell cycle changes in human neoplasms and vegetal cells. Toxicol Lett 285: 121-131.

FERREIRA PMP, LIMA DJB, DEBIASI BW, SOARES BM, DA CONCEIÇÃO MACHADO K, DA COSTA NORONHA J AND JÚNIOR GMV. 2013. Antiproliferative activity of Rhinella marina and Rhaebo guttatus venom extracts from Southern Amazon. Toxicon 72: 43-51.

FROLOV AV, AKHMETOVA LA AND VAZ-DE-MELLO FZ. 2017. Revision of the mainland species of the Neotropical genus Aegidium Westwood (Coleoptera: Scarabaeidae: Orphninae). J Nat Hist 51: 1035-1090.

GENIER F. 2010. A review of the Neotropical dung beetle genera Deltorhinum Harold, 1869, and Lobidion gen. nov. (Coleoptera: Scarabaeidae: Scarabaeinae). Zootaxa 2693: 35-48.

INGENITO LF, LIMA FC AND BUCKUP PA. 2013. A new species of Hyphessobrycon Durbin (Characiformes: Characidae) from the rio Juruena basin, Central Brazil, with notes on H. loweae Costa \& Géry. Neotropical Ichthyology 11: 33-44.

KERKHOFF J, NORONHA JDC, BONFILIO R, SINHORIN AP, RODRIGUES DDJ, CHAVES MH AND JÚNIOR GMV. 2016. Quantification of bufadienolides in the poisons of Rhinella marina and Rhaebo guttatus by HPLC-UV. Toxicon 119: 311-318.

MOREIRA CS, BRUNET D, VERNEYRE L, SÁ SMO, GALDOS MV, CERRI CC AND BERNOUX M. 2009. Near infrared spectroscopy for soil bulk density assessment. Eur J Soil Sci 60: 785-791.

NUNES C, MARTINHO VR AND MINUSSI CR. 2013. A New Method for the Prediction of Carbon Sequestration in Reforested Areas Using a Fuzzy-ART-BP Neural Network. In Proceedings on the International Conference on Artificial Intelligence (ICAI): 1.

NUNES LG, NUNES RV AND VAZ-DE-MELLO FZ. 2018. Taxonomic revision of the South American subgenus Canthon (Goniocanthon) Pereira \& Martínez, 1956 (Coleoptera: Scarabaeidae: Scarabaeinae: Deltochilini). Eur J Taxon: 437.

PAULA RC, SILVEIRA RDML, DA ROCHA MM AND IZZO TJ. 2015. The restoration of termite diversity in different reforestated forests. Agrofor Syst: 395-404.

TRINCA CT. 2014. Densidade populacional de felídeos e riqueza de mamíferos terrestres no sul da Amazônia. Universidade Federal da Paraíba, PhD. Thesis, 90 p. 